\title{
BIOTIC RESPONSE TO ACIDIFICATION OF LAKES - A REVIEW
}

\author{
${ }^{1}$ R. Raut* ${ }^{*}$ S. Sharma, ${ }^{2}$ R. M. Bajracharya \\ ${ }^{1}$ Aquatic Ecology Centre, School of Science, Kathmandu University, Dhulikhel, Kavre \\ ${ }^{2}$ Department of Environmental Science and Engineering, Kathmandu University, \\ Dhulikhel, Kavre, Nepal \\ *Corresponding author: rosha@ku.student.edu.np \\ Received 17 November, 2011; Revised 19 February, 2012
}

\begin{abstract}
Acidification has far reaching environmental and ecological impacts. It brings change in the chemical, physical and biological composition of the environment and thereby affects the behavior and adaptation of the organisms in the changing environment. In this paper research articles published on acidification and its effect on the biota, with focus on high altitude lakes, are reviewed covering phytoplankton (diatoms), macrophytes, zooplankton, and benthic macro invertebrates. The areas considered in review highly affected by acidification are Scandinavia, Central Europe, Scotland, Canada, United States and Sweden. The specific causes of acidification, its problem and prospect in the high altitude Himalayan lakes with scope and the technique of the studies are also discussed.
\end{abstract}

Key words: Acidification, Aquatic biota, High altitude, Himalayan lakes, Paleolimnogy

\section{INTRODUCTION}

Freshwater ecosystem or lake becomes acidification due to the chemical, physical and biological changes [1] which affects all aspects of the natural environment such as soil, water, flora and fauna. Acidified waters undergo chemical and biological changes and affects in relative abundance of species [2]. These changes are mainly due to the combined outcome of hydrogen ions $\left(\mathrm{H}^{+}\right)$deposited directly on water surfaces and it has also indirect effects on catchments soils and vegetation. Among the freshwater ecosystems, the high altitude lakes are pristine habitats; due to their remote in location and are almost undisturbed by direct anthropogenic activities [3]. Despite their remote location, alpine freshwater ecosystems are subject to natural and human-induced environmental changes due to acidification, eutrophication, global warming and UV radiation [4]. Especially, high mountain lakes are more susceptible to atmospheric inputs than lowland lakes due to factors like climate, shallow soils, small watersheds and rapid flushing rates [5]. The climatic factor drought may also accelerate acidification [6]. High elevation catchments are characterized by dilute surface waters, small terrestrial area, limited vegetative cover, thin soils and low rates of bedrock weathering $[7,8]$. As such, they are sensitive to surface water acidification, eutrophication and atmospheric acid deposition [7,5]. During the last two decades the study of high mountain lakes has focused on eutrophication processes [9, 10] acidification in Europe [11,12] and in America [13] and climatic changes [14] as mentioned in [15].

\section{LAKE ACIDIFICATION}

The phenomenon of acidification of lakes is not a new problem; it has been ongoing processes since pre-historic times. The effect of acidification on soil and plants have been first recorded since the middle of $19^{\text {th }}$ century and studied by [16], especially in relation to 
lakes and rivers, since the 1920s but in the last 25 - 30 years acidification has became a major environmental problem due to decline of forest in various parts of Scandinavia and Central Europe [17] and some fish species have decline as well. Although, it was not generally accepted by scientists until 1970s [18]. The absence of fish and most of the life forms in the lake was first confirmed by [19], this was due to the water being acidic ( $\mathrm{pH}$ 4.3). Acidification of freshwater was first identified in Scandinavia during the early (1970s) since then thousand of lakes, rivers, streams have become acidified and its major impacts are found in the countries; Scandinavia, Central Europe, Scotland, Canada, United States and Sweden [20].

\section{STUDY OF THE LAKE ACIDIFICATION}

Lake Acidification is studied by Paleolimnological research or fossils. Paleolimnological records of remote lakes are a useful tool to know the effects of global warming on limnology, where the climate signals are maximized due to less human impact $[21,22,23$, and 24]. High altitude remote mountain lakes are among the few ecosystems which are almost exclusively affected by climate change and lakes are particularly sensitive to temperate change [25]. Even small temperature changes of 1 to $2^{0} \mathrm{C}$ can have large hydrological, physical, chemical and biological effects in ecosystems and disturbed. Historical analysis suggests that such acidification has been occurring since large - scale industrial emissions began [26] and this is confirmed by the Paleolimnological analysis of fossil diatoms in lake sediments (Battarbee, 1984). Diatoms are very sensitive to acidification and recorded changes in species assemblages from sediment cores can provide a great deal of information about the progression of Lake Acidification [27]. Physical, chemical and biological informations are preserved in sediment profiles which is used to estimates background conditions of aquatic ecosystems to detect changes due to anthropogenic impacts [3]. As sediment layers can be dated quite accurately, the chronology of environmental stress and also their causes (e.g. acidification) can be determined $[28,29,30,31]$. Sediment diatoms indicate greater acidification than indicated by chemical models and they stressed the sensitivity of planktonic diatoms to acidification [32]. According to [33], the Lake sediments are natural archives of climatic and environment-related proxies (e.g., photosynthetic pigments, pollen, diatoms, and organic geochemistry).

\section{SOURCES OF ACIDIFICATION}

Industrial and vehicular air pollution is the main source of acidification which causes the destruction of freshwater ecosystems. Burning of fossil fuels, vehicle emission produces sulphur dioxide $\left(\mathrm{SO}_{2}\right)$ and oxides of nitrogen $\left(\mathrm{NO} \& \mathrm{NO}_{2}\right)$ and these are the major sources of acid precipitation. These gases enter into the atmosphere and transform into $\mathrm{H}_{2} \mathrm{SO}_{4}$ and $\mathrm{HNO}_{3}$, which then acidify the water vapors and fall on the Earth's surface as acid rain [34]. The term "acid rain" was first coined in 1852 by R. Angus Smith as mentioned by [35]. Besides rain, atmospheric deposition are in other forms like snow, fog, sleet, haze etc. which leads to acidification of exposed land and surface water bodies [18]. Therefore, acidification of surface waters can result from direct deposition of pollutants into lakes and streams or more commonly, through runoff and soil through flow from the surrounding catchments [20]. A very small percentage enters directly into surface waters, but the majority of it enters through the catchment, so there are also chances of contamination of the water bodies by toxic metals like aluminum, manganese, iron, zinc, copper, nickel, 
lead, mercury etc which are harmful to aquatic organisms and human being as well. Globally, 2 to 3 times more $\mathrm{SO}_{2}$ and $\mathrm{NOx}$ are released into the atmosphere as anthropogenic emissions than naturally as in organic elements (for example sulfur from volcanoes) or organic compounds from soil, wetlands and marine ecosystems [36]. This emitted gases oxide has a median transport range of about $400 \mathrm{~km}$ per day, while the mean transport distance can be 400 to $1200 \mathrm{~km}$. Consequently, these oxides are transported hundreds or even thousands of kilometers from the source of emission before falling back onto the earth surface [37]. This trend has taken on serious proportions after the industrial revolution in the $1800 \mathrm{~s}$, but has become acute with increasing human population pressures and advancement of technology in past few decades. Therefore, long range transports of pollutants are also harmful impact.

\section{BIOTIC RESPONSE TO ACIDIFICATION}

There is abundant literature on biotic response to acidification. Response of acidification to phytoplankton communities based on the studies of [38] and [39] is synthesized below. Studies on zooplankton are by [40, 41, 42, 43] Benthic algae by [44, 45, 46]]. Effects of acidification on diatom taxa were initiated by [47]. [48] Presented a historical review on the distribution of certain diatoms closely linked to $\mathrm{pH}$ based on paleoacidification work. [49] Surveyed 1,500 lakes for study on the effect of acidification on mollusks in Norwegian lakes. Norwegian lakes have been studied for the effects of acidification also by $[50,51,52,2]$ mentioned $[44,53]$ as particularly relevant and synthesized the effects of acidification on microbial activity and composition, macrophytes, benthic algae, phytoplankton, zooplankton, benthic macroinvertebrate, and fish and birds.

\section{PHYTOPLANKTON}

Various research works has proven that the distributions of phytoplankton communities are effected by acidification. The highest biomass was found in the small, shallow phosphorus rich acidified lake Starolesnianske [54]. The most important aboundant groups occurring in this lake were green flagellates (Chlamydomonas) and Dianoflagellates (Peridinium inconspiumm, Woloszynskia ordinate, Katodinium) and non motile (Chroococcus, Oocystis, centric diatoms etc.). Phytoplankton and littoral epilithic diatoms were studied in high mountain lakes to investigate the acid sensitivity of lakes, which indicated by very low alkalinity values and by identification of algal species assemblages considered as indicators of oligotrophy and acid sensitivity respectively [55]. The phytoplankton communities were dominated by flagellated algae (Chlorophyceae and Dianophyceae) and also several Coccal green algae. Where planktonic diatoms were almost completely absent but littoral diatoms communities were dominated by alpine and acidophilus taxa mainly (Achnanthes and Eunotia). Diatoms analysis of lake sediment cores reveals striking changes up-section. A clay unit at the base contains a marine - littoral diatoms flora. The appearance and increasing abundance of acidophilus diatoms reveal increasing acidification which culminates in the top $2 \mathrm{~cm}$. The modern lake- bottom sediments are dominated by acidobiontic species that develop at $\mathrm{pH}$ values $<5.5$ [56]. Water $\mathrm{pH}$ is acidic ( $\mathrm{pH} 4.5$ ), where most of the lives form is absent. Freshwater diatoms have long been used in palaeolimnological studies. Because of their life strategies (e.g. phytoplanktonic or periphytic), diatoms are specific indicators of microhabitat [22]. Moreover, diatom succession is influenced by differences in substrates (e.g. mosses, bryophytes or stones) and in the physical environment: thickly silicified diatoms require more water turbulence to 
maintain their position in the water column, and therefore a relatively long ice-free period [21].

\section{MACROPHYTES}

Aquatic macrophytes are part of a complex interactive lake system and influenced by both biotic and abiotic components and these factors are also limiting for growth and reproduction of macrophytes [1]. Thus, they are either directly or indirectly affected by acidification. Macrophytes are important in lake productivity, nutrient cycling as well as a habitat for both invertebrates and vertebrates. A number of factors may affect macrophytes in lakes undergoing acidification, such as the increase in concentrations of anions $\mathrm{H}^{+}, \mathrm{SO}_{4}{ }^{2-}$ , $\mathrm{NO}_{3}^{-}$and cations $\mathrm{Al}^{3+}, \mathrm{Ca}^{2+}$ and $\mathrm{Mg}^{2+}$ leached from surrounding soils [57]. Similarly physical changes may also occur in the lake, i.e., light environment and thermal structure of the lake. Macrophytes are also affected by biotic changes in bacterial, phytoplankton, periphyton, zooplankton invertebrates and vertebrate communities and also changes in responses to other macrophytes in the same community. Different communities of macrophytes occur in lakes of differing $\mathrm{pH}$ level [58]. The clear water having the $\mathrm{pH}$ 4.66.5 are characterized by a dominance of Isoetids (Lobelia dorimanna, Littorella uniflora and Isoetes sps), Juncus bulbosus, Nymphaea alba etc [59]. However, if $\mathrm{pH}$ is lower than that of the lakes can became dominated by Sphagnum [60, 61]. Similar study was also carried out on by [62] on "Littoral macroinvertebrates as indicators of Lake Acidification within the U.K."

\section{ZOOPLANKKTON}

Zooplankton also tends to be affected by acidification; while the community biomass changes little, there is loss of change to less sensitive species [2]. An average of 50 per cent of macrozooplankton and rotifer species is lost in eastern Canada due to decline of $\mathrm{pH}$ in 4.8 [41]. Crustacean zooplankton and rotifers richness showed a distinct impoverishment upon acidification and small species tend to become more dominant [40]. Gradual decrease in abundance of calanoid copepod with decreasing $\mathrm{pH}$ values [63]. At $\mathrm{pH}$ units <5 significant variations in zooplankton species composition and abundance are also observed [64], along with a decrease in diversity in the 5-6 $\mathrm{pH}$ unit range [65, 66]. There is some debate about the sensitivity of Daphnia longispina to acidification: while some studies show that this species is replaced by Eubosmina longispina when $\mathrm{pH}$ goes down to 5.5 units [67], there is also evidence that the species can develop acid-resistant morphs/clones, and also able to grow well even at low $\mathrm{pH}[68]$.

\section{BENTHIC MACROINVERTEBRATES}

Benthic invertebrates are a diverse and generally abundant group with a wide range of environmental tolerances and as good indicators of environmental quality [69]. Benthic macroinvertebrates, a group of bottom dwelling organism's crustaceans and mollusks, many species that are sensitive to a lowered $\mathrm{pH}$. The relationship between acid conditions and the presence and absence of certain benthic macroinvertebrate species have been used to assess the effect of acid stress on ecosystems [70, 71, and 72]. Amphipods, crayfish and other macroinvertebrate appear under low $\mathrm{pH}$ level to hardening of exoskeleton both in lotic and lentic systems, while snails (gastropods) disappeared when the $\mathrm{pH}$ decline to $5.2-$ 5.0 [2]. The freshwater amphipod, Gammarus lacustris is rare at $\mathrm{pH}<6.6$ and absent at $\mathrm{pH}<6.0$ in Norwegian lakes [51]. The mollusks (snail and mussels) are highly acid 
sensitive and disappeared at $\mathrm{pH}<6$, while many more common species were lost and very few of them are able to maintain themselves at $\mathrm{pH}$ less than 4.4-4.6. Similar findings were made by [49] in some species of mollusks, leeches and insects in most of the affected areas of New England, US. Insect species like mayflies (Ephimeroptera), cadisflies (Trichoptera) and stoneflies (Plecoptera) are particularly acid sensitive indicators [73].

\section{ACIDIFICATION IN THE HIGH ALTITUDE HIMALAYAN LAKES}

The first investigations on high mountain lakes date back to the origins of limnology in the last decades of the nineteenth century [74, 75]; however, it has been neglected for long periods. In general limnological studies in lakes were considered earlier than running waters and algae have been investigated later than zoobenthos as mentioned in [4]. Moreover, limnological research in the Himalayan has been carried out since the beginning of the century $[76,77]$. Most of the environmental research in the Himalayas from the 50s to the $70 \mathrm{~s}$ was carried out during mountaineering expeditions. Italian Institute of hydrology has been carried out research on acidification in high mountain lakes of the Italian Alps since the seventies, recently started a detailed investigation on the deposition characteristics and high mountain lakes of the Himalaya [78].

Although, early studies were mainly focused on the biology and the geographical distribution of the various species, after then [79] studied the evaluation of pollutant loads from the atmosphere and their possible effects in terms of acidification or eutrophication i.e. enrichment of lake waters with nitrogen compounds. Most of the recent studies have been carried out in the framework of projects funded by the European Commission, in collaboration with several other European groups, with the aim of comparing the present status of lakes and the processes occurring in them, in different European mountain ranges i.e. Scandinavian Alps, Alps, Tatra Mountains, and Pyrenees [80, 81, 82, 83, and 84]. The European Commission-supported project on Acidification of Mountain Lakes: Palaeolimnology and Ecology (AL: PE) is concerned with the study of remote mountain lake ecosystems and their response to different levels of acid deposition $[5,82]$. The study of acidification in remote mountain-lake ecosystems requires accurate historical information. However, historical, chemical and biological data for remote lakes are scarce for the last 200 yrs [85]. The reconstruction of Lake Acidification histories from the sediment record is therefore an important facet of the study of these environments. Many of these studies were performed on high-altitude lakes in Kashmir and Sikkim in the northwest Himalayas [86, 87, 88, 89, 90, 91] while it has been comparatively little research in the eastern, Nepalese Himalayas [92, 93]. A major contribution to the study of the morphometry and the chemistry of the lakes in the Everest area by Löffler's study was made in the 90s with the Ev-K2-CNR project [94, 95] along with other work of a purely hydro biological nature [96, 97], this took up the studies of thirty years earlier [98], extending and partially completing the work which had been done on some of the same lakes.

These freshwater environments have simplified biological communities, formed by a relatively low number of species, endemic or adapted to extreme environmental conditions. Mountain lakes are treasures of biological diversity. Located as they are in remote areas, away from human settlements, these lakes are elective sites for studying global change phenomena and the global scale transport of pollutants [99]. The research in the field of 
limnology of high mountain lakes, with a considerable financial support provided from the EU, particularly important among these projects is the Ev-K2-CNR Project on the Long Distance transport of micro-pollutants, a research program developed as collaboration between the Italian Research Council and the Royal Nepal Academy of Science and Technology. High mountain regions are strategic area for biodiversity conservation and for water and energy supply [100]. Therefore it has been proposed to include the Alps in the UNESCO list of environmental and cultural heritage. Khumbu valley in the Himalaya (Nepalese) has already been included in this list [4]. However, knowledge on mountain ecosystem is still inadequate [101]. The results of an extensive survey showed that many high mountain lakes have low alkalinity and are therefore sensitive to acidic inputs [102] as mentioned in [103].

\section{CONCLUSIONS}

High altitude freshwater lakes are highly fragile and rare ecosystems. They are generally not disturbed by direct anthropogenic activities due to remote location and high elevation. However, the water qualities in these lakes are, nonetheless, affected by atmospheric acid deposition by long range transport of air borne pollutants. The combustion of fossil fuels from industries, as well as, vehicle emissions produces sulphur dioxide and oxides of nitrogen when these gases enter into the atmosphere and transform into $\mathrm{H}_{2} \mathrm{SO}_{4}$ and $\mathrm{HNO}_{3}$, then acidify the water vapors and fall back to the Earth's surface as acid rain and cause acidification. Acidification of surface water bodies may be either natural or anthropogenic; however, it is a serious stressor for environmental change and has becoming a global threat to aquatic life. Aquatic habitats such as lakes and rivers are primary receptor of such environmental contamination from various sources. Aquatic biodiversity both micro and macro are the first organisms to suffer from and adapt to the impact of environmental contamination and they are very sensitive indicators for ecosystem changes as well. Thus, acidification is widespread phenomenon, especially in the developed countries like Europe and USA. However, it is also becoming a major problem in developing countries of Asia, particularly near populated urban and industrial areas. Acid rain is destroying our freshwater ecosystems, and if preventive measures or conservation is not taken in the near future, ultimately many aquatic ecosystems will be destroyed.

\section{REFERENCES}

[1] Farmer A M, The effects of lake acidification on aquatic macrophytes - A review, Dept of biology, Imperial College, Silwood Park, Ascot, berks SL5 7PY, UK, Environmental pollution 65 (1990) 219.

[2] Kalff J, Limnology, Prentice - Hall Inc Upper saddle. River (2002), NJ97458 ISBN $0-13-033775-7$.

[3] Koinig K A, Sommaruga-Wograth S, Schmidt R, Tessadri R \& Psenner R, Acidification processes in high alpine lakes, A.A. Balkema Publishers Rotterdam, The Netherlands (1998) INBN: 905410780 4, es 45.

[4] Cantoneti M, Corradini G, Juttner I \& Eileen J Cox, Diatom assemblages in high mountain streams of the Alps and the Himalayaya, Nova Hedwigia, Beiheft 123 (2001) 37. 
[5] Mosello R., Wathne B M, Lien L \& Birks H J B, Al: PE projects: Water chemistry and critical loads. Water, Air and Soil Pollution 85 (1995) 493.

[6] Arts G H P, de Haan A J, Sicbum M B \& Verheggen G M, Extent and historical decline of Dutch soft waters. Proc. Konin. Nerderl. Akad. Wetenschappen (Series C), 92 (1989) 281.

[7] Psenner R, Chemistry of high mountain lakes in siliceous catchments of the Central Eastern Alps. Aquat. Sci., 51 (1989) 108.

[8] Drever J I \& J Zobrist, Chemical weathering of silicate rocks as a function of elevation in the southern Swiss Alps. Geochin. Cosmochim. Acta, 56 (1992) 3209.

[9] Heinonen P, Quantity and composition of phytoplankton in Finnish inland waters. Publ. Water Res. Inst. 37, Vesihallitus-National Board of Waters, Finland, (1980).

[10] Brettum P, Alger som indikatorer på vannkvalitet i norske innsjøer. Planteplankton. NIVA Report (1989) 111.

[11] Willén E, S Hajdu \& Y Pejler, summer phytoplankton in 73 nutrient-poor Swedish lakes - classification, ordination and choice of long-term monitoring objects. Limnologica, 20 (1990) 217.

[12] Nauwerck A, A survey on water chemistry and plankton in high mountain lakes in northern Swedish Lapland. Hydrobiolgia, 274 (1994) 91.

[13] Schindler D W, K H Mills, D F Malley, D L Findlay, J A Shearer, I J Davies, M A Turner, G A Linsey \& D R Cruikshank, Long-term ecosystem stress: the effect of years of experimental acidification on a small lake. Science, 228 (1981)1395.

[14] Halac, M Felipe, L Camarero, S Sommaruga-Wögrath, R Psennre, R Catalan \& R. Sommaruga, An in situ enclosure experiment to test the solar UV-B impact on plankton in a high altitude lake.1) lack of effect on phytoplankton composition and growth. J. Plankton Res., 19 (1997)1671.

[15] Tolotti M, Phytoplankton and littoral epilithic diatoms in high mountain lakes of the Adamello-Brenta Regional Park (Trentino, Italy) and their relation to trophic status and acidification risk, J. Limnol.,60 (2) (2001)171.

[16] Erisman J W \& Draaijers G P J, Studies in Environmental Science 63.Elsevier, Amsterdam (1995).

[17] Hallbacken L \& Tamm C O, Changes in soil acidity from 1927-1882/84 in a Forested area of south west Sweden. Scandinavian Journal of Forest Research 1(1986) 219. 
[18] Macvicar S, Acid Rain and How it Affects the Aquatic Ecosystem, Gly 1073 (1998).

[19] Kaminski G, Lalande H Doige, W Gordon, A Mesher, C, Lake Isiurqutuuq - the acid lake of Nunavik. Phase one: assessment of problem. Rep. 12-245. Kuujjuaq Research Center, Makivik Corporation, Kuujjuaq, QU (1995) 24.

[20] Buchdahl J, (1998); Freshwater Acidification [online] Available HTTP://WWW.DOC.MMU.AC.UK/ARIC/FRESHWAT.HTML, May 2011).

[21] Smol J P, Paleoclimate proxy data from freshwater Arctic diatoms. Verhandlungen. Der Internationale Vereingung von Limnologie. 23 (1988) 837.

[22] Smol J P, I R Walker \& P R Leavitt, Paleolimnology and hindcasting climatic trends. Verh. Internat. Verein. Limnol., 24 (1991) 12140.

[23] Battarbee R W, in B. Frenzel (ed.), Evaluation of Climate Proxy Data in Relation to the European Holocene, Gustav Fisher Verlag, Stuttgart, (1991 )149.

[24] Pienitz R, J P Smol \& H J B Birks, Assessment of freshwater diatoms as Quantitative indicators of past climatic change in the Yukon and Nortwest Territories, Canada. J. Paleolimnol., 13 (1995) 21.

[25] Koinig K A, Schmidt R, Wograth S S, Tessadri R \& Psenner R, Climate change as the primary cause for $\mathrm{pH}$ shifts in a high alpine lake. Water Air and Soil Pollution 104 (1997)167.

[26] Cowling E B, An historical perspective on acid precipitation. In Acid Rain/Fisheries, ed. R E Johnson. American Fisheries Society, Bethesda, Maryland, (1982) 15.

[27] Battarbee R W, Diatom analysis and the acidification of lakes. Phil. Trans. R. Soc. B, 305 (1984) 451.

[28] Smol J P, Paleolimnology: an important tool for effective ecosystem management. Journal of Aquatic Ecosystem Health, 1 (1992) 49.

[29] Dixit S S, J P Smol J C Kingston \& D F Charles, Diatoms: powerful indicators of environmental changes. Environmental Science and Technology 26 (1992) 23.

[30] Battarbee R W \& D Charless, Lake Acidification and the Role of Paleolimnology. In: Acidification of freshwater Ecosystems, Implications for the Future, C.E.W. Steinberg, and R.E. Wright editors, john Wiley \& Sons, new York, (1992) 51.

[31] Renberg I. T Korsman \& H J B Birks, Prehistoric increases in the pH of acid Sensitive Swedish lakes caused by land-use change. Nature 362 (1993) 824. 
[32] Huttunen P, Kenttamies K, Liehu A, LiuKkonen M, Nuotio T, Sandman O \& Turkia J, Paleolimnological evaluation of the recent acidification of susceptible lakes in Finland. In Acidification Finland (ed. P. Kauppi, K. Kenttamies \& P. Anttila). Berline: Springer-verlag (1989), (In the Press).

[33] Lami A, P Guilizzoni, A Marchetto, R a Bettinetti \& D J Smith, Palaeolimnological evidence of environmental changes in some high altitude Himalayan lakes (Nepal), Mem. Ist. Ital. Idrobiol 57 (1998) 107.

[34] Hare S, Laura C, Rebecca T \& Buchdahl J, Atmospheric Climate \& Environment Information Programme, aric, Manchester Metropolitan University, Chester Street, Manchester MI5GD, (2002), .

[35] Smol J P, Pollution of Lakes and Rivers, A paleoenvironmental perspective second edition, (2008) 88.

[36] Galloway J N, Acid deposition: Perspectives in Time and Space. Water. Air and Soil Poll. 85 (1995) 15.

[37] Schwartz S E, Acid Deposition: Unraveling a Regional Phenomenon. Science, 243 (1989) 753.

[38] Almer B, W Dickson, C Ekstorm \& E Hornstrom, Sulfur Pollution and the AquaticEcosystem, (1978) 271.

[39] Findlay D L \& S E M Kasian, Phytoplankton Communities of Lakes Experimentally aAcidified with Sulfuric and Nitric Acids. Can J. Fish. Aquat. Sci. 47 (1990) 1378.

[40] Dillon P J, N D Yan \& H H Harvey, Acidic deposition: Effects on Aquatic Ecosystems. CRC Critical Rev. in Env. Control 13 (1984)167.

[41] Doka S E, M L Mallory, D K McNicol, C K Minns Species Richness and Species Occurrence of Five Taxonomic Groups in Relation to $\mathrm{pH}$ and Other Lake Characteristics in Southeastern Canada. Can. Tech. Rep. Fish Aquat. Sci. 2179 (1997) 62.

[42] Gunn J M \& K H Mills, The Potential for Restoration of Acid Damaged Lake Trout Lakes. Restoration Ecology 6 (1998) 390.

[43] Uutala A J \& J P Smol, Paleolimnological reconstruction of Long - term Changes in Fisheries Status in Sudbury Lakes. Can. J. Fish. Aquat. Sci., 53 (1996) 174.

[44] Schindler D W, T M Frost, K H Mills, P S Chang, I J Davies, D L Findlay, D F Malley, J A Schearer, M A Turner, P J Garison, C J Watras, K Webster, J M Gunn, P L Brenzonik\& W A Swenson, Comparison Between Experimentally and 
Atmospherically - acidified Lakes during stress and Recovery. Proc. Roy. Soc. Edinburgh 97B (1991) 193.

[45] Planas D, Acidification Effects. In R. J. Stevenson, M.L. Bothwell, and R L Rowe, Algal Ecology, Freshwater Benthic Ecosystems. San Diego: Acad. Press (1996). 497.

[46] Jeffries D S (ed), Canadian Acid Rain Assessment, The Effects on Canada's Lakes, Rivers and Wetlands. Burlington: Env. Canada. Vol 3 (1997).

[47] Hustedt F, Systematische und Okologische Untersuchunge uber der Diatomeen Flora von Java, Bali, Sumatra. Rchiv fur Hydrobiologie (Suppl.), (1937- 1939), 15 $\& 16$.

[48] Battarbee RW, Smol J P \& Merilainen J, Diatoms as indicator of $\mathrm{pH}$; an Historical review. In J. P. Smol, R.W.Battarbee, R. B. Davis, and J. Merilainen (eds), Diatoms and lake acidity. Dordrecht: Dr. W. Junk Publishers, (1986) 5

[49] Schindler D, W S E M Kaisan \& R H Hesslein, Biological Impoverishment in Lakes of the Midwestern and Northeastern United States from Acid Rain . Env. Sci. Technol. 23 (1989) 573.

[50] Jensen K W \& E Snekvik, Low pH Levels Wipe out Salmon and Trout Population in Southernmost Norway. Ambio., 1 (1972) 223.

[51] Qkland J \& K A Qkland, pH Level and Food Organisms for Fish: Studies of 1,000 Lakes in Norway. In D. Drablos and A. Tolian (eds.), Ecological Impact of Acid Precipitation. Oslo: SNSF - Project \# 1432. (1980) 326.

[52] Sevaldrud I H, I P Muniz, S Kalvenes, Loss of Fish Populations in Southern Norway. Dynamics and Magnitude of the Problem. (1980) 350.

[53] Brezonik P L, J G Eaton, T M Frost, P J Garrison, T K Kratz, C E Mach, J H McCormick, J A Perry, W A Rose, C J Sampson, B C L Schelley, W A Swenson, \& K E Webster, Experimental Acidification of little Rock Lake, Wisconson: Chemical and Biological changes over the pH Range 6.1 to 4.7 Can. J. fish. Aquat. Sci., 50 (1993)1101.

[54] Fott J, Blazo M, Stuchlik E \& Strunecky O, Phytoplankton in three Tatra Mountain lakes of different acidification status. J. Limnol., 58(2) (1999) 107.

[55] Monica T, Phytoplankton and littoral epilithic diatoms in high mountain lakes of the Adamello-Brenta regional Park (Trentino, Italy) and their relation to trophic status and acidification risk, J. Limnol., 60 (2) (2001) 171.

[56] Cameron E M, C L Prevost, M McCurdy, G E M Hall, B Doidge, Recent (1930s) natural acidification and fish- kill in a lake that was an important food source for an 
inuit community in northern Quebec, Canada, Journal of Geochemical Exploration 64 (1998)197.

[57] Morrison B R S \& Battarbee, R W, Effects of freshwater flora and fauna excluding fish). In Acid Rain and Britain's Natural Ecosystems. eds M. R. Ashmore. J N B Bell \& C Garretty. Imperial College Centre for Environmental Technology, London, (1988) 71.

[58] Pearsall W H, The development of vegetation in the English lakes, considered in relation to the general evolution of glacial lakes and rock-basins. Proc. R. Soc. Lond. B, 92 (1921) 259.

[59] Mishra R D, Edaphic factors in the distribution of aquatic plants in the English lakes. J. Ecol., (1938) 26

[60] Ohle W, der Schwefelsaure Tonteich bei Reinbek. Arch. Hydrobiol., 30 (1936), 604.

[61] Vallin S, Zwei azidotrophe Seen im Kustengebeit von Nordschweden. Rep. Inst. Fresh. Res. Drottningholm, (1996) 34.

[62] Macfarland B, F Carse \& L Sandin, Literal macroinvertebrates as indicators of Lake Acidification within the UK. Aquatic Conserv: Mar. Freshw. Ecosyst. (2009).

[63] Fott J, M Prazakova, E Stuchlik \& Z Stuchlicova, Acidification of lakes in Sumava (Bohemia) and in the High Tara Mountains (Slovakia). Hydrobiologi, 274 (1994) 37.

[64] Locke A \& W G Sprules, Effects of Lake acidification and recovery on the stability of zooplankton food webs. Ecology 75 (1994) 498.

[65] Brezonik P L, L Crisman \& R L Schulze, Planktonic communities in Florida soft water lakes of varying pH. Can. J. Fish. Aquat. Sci, 41 (1984) 46.

[66] Watras C J \& T M Frost, Little Rock Lake (Wisconsin): perspective on an Experimental ecosystem approach to seepage lake acidification. Arch. Envr. Contam. Toxicol., 18 (1989)157.

[67] Nilssen J P, An ecological jig- saw puzzle; Reconstructing aquatic biogeography and $\mathrm{pH}$ in an acidified region. Nat. Swed. Board. of Fish. Inst. Freshwat. Res. Drottingholm, 61 (1984)138.

[68] Schmidt R, A Klaus, J Fott, Z Rehaova, V Straskrabova \& J Vesely, Acidification of Bohemian Lakes. Recent trends and historical development. Im Auftrag des Bundeministerium fur Wissenschaft und Forschung und der Osterreichen Akademie der Wissenschaften, (1992) 58. 
[69] Rosenberg D M \& Resh V H, Freshwater bio-monitoring and benthic macroinvertebrates. Chapman and Hall, New York, (1993) 488.

[70] Raddum G G, Rossel B O \& Bowman J, Workshop on biological assessment and monitoring; evaluation and models. NIVA- report 4091-99, ICP Waters report 50/99. (1999) 96.

[71] Davy-Bowker J Murphy JF, Rutt G P et al, The development and testing of macroinvertebrate biotic index for detecting the impact of acidity on streams. Arch Hydrobiol 163 (2005) 383.

[72] Furse M, Hering D Moog O et al, the STAR project context, objectives and approaches. Hydrobiologia 566 (2006) 3

[73] Schartau A K, S J Moe L Sandin B MacFarland \& G G Raddum, Macroinvertebrate indicators of Lake Acidification: analysis of monitoring data from UK, Norway and Sweden. Aquat Ecol, $42 l$ (2008) 293.

[74] Pero P, Ricerche e studi sui laghi valtellinesi. - Nuova Notarisia, 4 (1893) 47.

[75] Zschokke F, Die Tierwelt der Juraseen - Revue Suisse Zoologie, 2 (1894) 349.

[76] Sars G, on the crustacean fauna of central Asia. Pt. II Cladocera. Ann. Mus. Zool. De l'Acad. Imp. Sci., St.-Petersbourg, 8 (1903) 157.

[77] Hutchinson G E, Limnological studies in Indian Tibet. Int. Rev. ges. Hydrobiol., 35 (1937)134.

[78] Tartari G A, P Panzani, L Adreani, A Ferrero \& C De Vito, Lake cadastre of Khumbu Himal Region: geographical - geological - limnological data base. In: A. Lami \& G. Giussani (Eds), Limnology of high altitude lakes in the Mt Everest Region (Nepal). Mem. Ist. ital. Idrobiol., 57 (1998)151.

[79] Marchetto A, The study of high mountain lakes in the activity of the Istituto Italiano Di Idrobiologia. In: A. Lami \& G. Giussani (Eds), Limnology of high altitude lakes in the Mt Everest Region (Nepal). Mem. Ist. ital. Idrobiol, 57 (1998) 1.

[80] Mosello R, A Barbieri, G Bendetta, A Boggero, A Marchetto, R Psenner, D Tait \& $\mathrm{G}$ A Tartari, Quantification of the susceptibility of alpine lakes to acidification. Mem. Ist. ital. Idrobiol, 52. (1993) 355.

[81] Marchetto A, R Mosello, R Psenner, A Barbieri, G Bendetta, D Tait \& G A Tartari, Evaluation of the level of acidification and the critical loads for Alpine lakes. Ambio, 23 (1994)150.

[82] Wathne B M Partick, S T, Monteith, D \& H Barth (Eds). AL: PE ROJECT PART 1: AL: PE - Acidification of Mountain Lakes: Palaeolimnology and Ecology. AL: PE 
1 Report for the period April 1991 - April 1993. Ecosystems Research Report No 9. European Commission, D-G XII, Brussels: (1995) 296.

[83] Camarero L, J Catalan, A Boggero, A Marchetto, R Mosello \& R Psenner, Acidification in high mountain lakes in Central, Southwest and Southeast Europe (Alps, Pyrenees, Pirin). Limnologica, 25 (1995) 141.

[84] Patrick S, RW Battarbee, B Wathne \& R Psenner, Measuring and modelling the dynamic response of remote mountain lake ecosystems to environmental change: an introduction to MOLAR project. Proc.of the Head Water '98 Conference, Meran/Merano, Italy, IAHS Publ.248, April (1998) 403.

[85] Cameron N G, H J B Birks, V J Jones, F Berge, J Catalan, R J Flower, J Garcia, B. Kawecka, K A Koinig, A Marchetto, P Sánchez-Castillo, R Schmidt, M æiçko, N Solovieva, E ætefková \& M Toro, Surface-sediment and epilithic diatom $\mathrm{pH}$ calibration sets for remote European mountain lakes (AL: PE Project) and their comparison with the Surface Waters Acidification Programme (SWAP) calibration set. Journal of Paleolimnology, 22 (1999) 291.

[86] Sharma A P \& M C Pant, Certain physico-chemical features, chlorophyll Concentration and phytoplankton population in high altitude lake. Tropical Ecology, 20 (1979) 101.

[87] Sharma P C \& M C. Pant, Species composition of zooplankton in two kaumann Himalayan lakes (U.P. India). Arch. Hydrobiol., 102 (1985) 387.

[88] Khan M A \& D P Zutshi, Contribution to high altitude limnology of the Himalayan system. I Limnology and primary productivity of the plankton community of Nilang Lake, Kashmir. Hydrobiologia, 75 (1980)102.

[89] Vass K K, A Wanganeo, H S Raina, D P Zutshi \& R Wanganeo, Summer limnology and fisheries of high mountain lakes of Kashmir Himalayas. Arch. Hydrobiol., 114 (1989) 603.

[90] Venu P, V Kumar \& M K Bhasin., Limnological survey of water bodies of the Sikkim Himalayas India. J. Human Ecology, 1 (1990)141.

[91] Zutshi D P, Limnology of high altitude lakes of Himalayan region. Verh. Int. Ver. Limnol., 24 (1991) 1077.

[92] Löffler H, High altitude lakes in Mt Everest region. Verh. int. Ver. Limnol., 17 (1969) 373.

[93] Aizaki M, A Terashima, H Nakahara, T Nishio \& Y Ishida, Trophic staus of T Tilitso, a high altitude Himalayan lake. Hydrobiologia, 153 (1987) 217. 
[94] Gosso E. G Tartari, S Valsecchi, S Ramponi \& R Baudo, Hydrochemistry of remote high altitude lakes in the Himalayan region. Verh. int. Ver. Limnol., 25 (1993) 800.

[95] Tartari G, G A Tartari, S Valsecchi \& M. CamussoCadastre and hydrochemistry of high altitude lakes in the Mount Everest region. Verh. int. Ver. Limnol., 26 (1997) 397.

[96] Manca M, P Cammarano \& T Spagnuolo, Notes on Cladocera and Copepoda from high altitude lakes in the Mount Everest Region (Nepal). Hydrobiologia, 287 (1994) 225.

[97] Manca M. \& G Mura, On Branchinecta orientalis Sars (Anostraca) in the Himalayas. Hydrobiologia, 356 (1997) 111.

[98] Löffler H, Diaptomus (Arctodiaptomus) jurisowitchi Nov. Spec. aus dem KhumbuGebit (Nepal). Khumbu Himal, Bd., 3, Lfg. 1, S (1968) 9.

[99] Manca M, D Ruggiu, P Panzani, A Asioli, G Mura \& A M Nocentini., Report on A collection of aquatic organisms from high mountain lakes in the Khumbu Valley (Nepalese Himalayas). In: A. Lami \& G. Giussani (Eds), Limnology of high altitude lakes in the Mt Everest Region (Nepal). Mem. Ist. ital. Idrobiol. 57 (1998), 77.

[100] Agenda 21 Programme of Action for Sustainable Development. Rio Declaration On Environment and Development - the final text of agreements negotiated by Governments at the United Nations Conference on Environment and Development (UNCED). Reo de Janeiro Brazil. Chapter 3, Sustainable mountain development. 314 June (1992).

[101] Lami A \& Giussani G (eds), Limnology of high altitude lakes in the Mt. Everest Region (Nepal), Memorie dell' Istituto di Idrobiologia., 57 (1998) 235.

[102] Thaler B, D Tait \& Bendetta, Effects of acidification on remote alpine lakes in the Province of Bolzano (South Tyrol, Italy). Final Report, Biologisches Labor Aut, (1991) 72.

[103] Tait D \& Thaler B, Atmospheric deposition and lake chemistry trends at a high mountain site in the eastern Alps, J. Limnol., 59 (1) (2000) 61. 